\title{
Gea
}

JURNAL PENDIDIKAN GEOGRAFI

\section{STUDI KOMPARATIF PENGGUNAAN MEDIA PETA TEMATIK DENGAN MEDIA CD INTERAKTIF TERHADAP KETERAMPILAN BERPIKIR KRITIS BAHAN AJAR POLA KEGIATAN EKONOMI PENDUDUK, PENGGUNAAN LAHAN, DAN POLA PEMUKIMAN (Studi Kasus SMP Negeri 1 Haurwangi Kabupaten Cianjur)}

\author{
Didi Suhandi, Mamat Ruhimat, Dede Rohmat \\ Program Studi Pendidikan Geografi, SPs UPI Bandung, 2013 \\ Email : didi.suhandi123@yahoo.com
}

\begin{abstract}
ABSTRAK
Penelitian ini dilatarbelakangi oleh proses pembelajaran yang kurang maksimal, yang hanya menekankan kepada kemampuan peserta didik untuk menghafal yang sifatnya kognisi. Peserta didik dipaksa untuk mampu mengingat berbagai teori dan konsep, tanpa diutamakan untuk memahami teori dan konsep yang diingatnya itu untuk diaplikasikan dalam kehidupan sehari-hari. Peserta didik kurang dilatih untuk memiliki keterampilan berpikir kritis, sehingga setelah mereka lulus, hanya pintar secara teoritis tetapi miskin aplikasi. Mengingat fungsi media pembelajaran cukup besar dalam proses pembelajaran, maka upaya yang dapat dilakukan yaitu mencoba mencari alternatif penggunaan media pembelajaran yang tepat. Dalam pelaksanaan penelitian dipilih dua media pembelajaran yaitu "media peta tematik" dan "media CD interaktif", yang secara teoritis diharapkan dapat meningkatkan keterampilan berpikir kritis.

Tujuan penelitian ini untuk mengetahui pengaruh dari kedua media pembelajaran yaitu "media peta tematik"dan "media CD interaktif". Penelitian dilakukan kepada peserta didik kelas VII dengan sampel penelitian masing-masing 39 orang dari "kelas eksperimen-1" dan "kelas eksperimen-2". "Kelas eksperimen-1" diberi perlakuan melalui proses pembelajaran dengan mengunakan "media peta tematik", sedangkan "kelas eksperimen-2" proses pembelajarannya menggunakan "media CD interaktif".

Hasil penelitian menunjukkan bahwa "kelas eksperimen-1" yang proses pembelajarannya menggunakan "media peta tematik" mengalami peningkatan sebesar 28,62 $\%$, dan "kelas eksperimen-2" yang proses pembelajarannya menggunakan "media CD interaktif meningkat 22,67\%. Hal ini berarti terdapat perbedaan 5,95\%. Hal ini menunjukkan bahwa penggunaan "media peta tematik" relatif lebih baik untuk meningkatkan keterampilan berpikir kritis pada peserta didik dibanding dengan penggunaan "media CD interaktif" walaupun perbedaannya hanya 5,95 .
\end{abstract}

Kata kunci: media peta tematik, keterampilan berpikir kritis. 


\title{
ABSTRACT \\ A COMPARATIVE STUDY THE USE OF "THEMATIC MAP MEDIA" AND "INTERAKTIVE CD MEDIA" TO CRITICAL THINGKING CAPABILITY \\ LEARNING MATERI PEOPLES ECONOMICAL ACTIVITIES PATERN, THE USE OF LAND AND HOUSING PATTERN (at SMP Negeri 1 Haurwangi Kabupaten Cianjur)
}

\author{
Didi Suhandi, Mamat Ruhimat, Dede Rohmat \\ Program Study Geografi Education, SPs UPI Bandung, 2013 \\ Email : didi.suhandi123@yahoo.com
}

This research is based on the less maximum learning process, which based on the students capability to remember things cognitifity. The students are forced to remember kinds of theories whithout understanding the theories and the concept they remember to gain the critical thingking, so after, they graduated, the students are theoretically smart but poor in application the function of teaching media plays a very imfortant role in teaching learning prosess, We need to find an alternative and appropriate teaching media. There are two medias chosen, the are thematic map media and interactive CD media to find. The goal of the research is to find out the influence of the two media thematic map media and interactive $\mathrm{CD}$ media. The research is done to seven grade student with 39 sample of experiment class- 1 and experiment class- 2 . Class experiment- 1 is treated by thematic map media white experiment class- 2 is treated by interactive CD media. The result of research shows that experiment class- 1 where the teaching process is using thematic map media is improping for about $28,62 \%$ and experiment class-2 where the teaching process is using interactive CD media is improving for about $22,67 \%$. There are $5,95 \%$ difference. It show that the use of tematif map media is better than the interactive CD media in improving the students critical thingking capability in 5,95\% of difference.

Key Words : Teaching Media, thematic map media, interactive CD, Critical thingking capability

\section{PENDAHULUAN}

Berpikir kritis bisa diartikan suatu proses penggunaan akal yang berwawasan luas, tidak menerima apa adanya, digunakan kapan saja, memiliki alasan-alasan yang bisa dipertanggung jawabkan, kreatif, objektif. Sehingga para ahli sependapat bahwa berpikir kritis termasuk ranah kognitif tingkat tinggi. Dalam proses pendidikan ada beberapa alasan mengapa peserta didik perlu belajar berpikir kritis. 1) Modal berharga bagi karir peserta didik, 2) harus mampu menyesuaikan diri dengan situasi dan kondisi zaman yang terus berubah. 3) tidak akan mudah menerima apa adanya, tidak cepat puas, 4) harus kreatif, 5) akan mudah dalam merefleksi dan mengevaluasi diri. Pada akhirnya peserta didik memiliki kualifikasi pendidikan untuk bekal hidup bermasyakat. 
Fakta hasil temuan di lapangan ada beberapa permasalahan yang ada hubungannya dengan kemampuan berpikir kritis, antara lain: 1) ketika tes (tes formatif, tengah semester, semester) masih banyak ditemui peserta didik yang belum mampu menggunakan nalarnya dalam mengisi soal-soal khususnya soal yang bersifat uraian. Bahkan ada beberapa peserta didik yang tidak mengisi jawaban soal uraian. 2) Ketika proses pembelajaran berlangsung peserta didik diberi kesempatan untuk mengajukan pertanyaan, menjawab pertanyaan, mengemukakan pendapat ternyata tidak banyak peserta didik yang mampu bertanya, menjawab dan mengemukakan pendapatnya.

Selain fakta di atas dalam proses pembelajaran terutama dalam hal penggunaan media pembelajaran, sepertinya efektifitas dan relevansi penggunaan media merupakan permasalahan yang sering dijumpai. Tidak sedikit ketika guru melaksanakan proses pembelajaran belum memanfaatkan media sebagai alat bantu secara maksimal. Padahal Media pembelajaran merupakan alat bantu bagi guru dalam menyampaikan materi belajar. Melalui bantuan media pembelajaran diharapkan peserta didik mampu termotivasi dalam mengikuti proses pembelajaran, sehingga tercipta proses pembelajaran aktif, interaktif, kreatif dan menyenangkan, sehingga peserta didik mampu mengembangkan segala potensinya termasuk di dalamnya keterampilan berpikir kritis. Proses pembelajaran yang menggunakan media akan lebih baik hasilnya dibandingkan dengan proses pembelajaran yang tidak menggunakan media.

Permendiknas No. 23 Th. 2006 SKL pasal 45 tentang sarana prasarana dipahami bahwa guru maupun peserta didik sangat memerlukan media pembelajaran; media pembelajaran belum memadai baik secara kuantitatif maupun kualitatif; masih terdapat kendala terkait dengan perawatan, perbaikan maupun penyimpanan media dan alat peraga pembelajaran; banyak media atau alat peraga pabrikan yang rusak dan tidak digunakan lagi karena mereka tidak tahu cara memperbaikinya, atau memperoleh komponen yang rusak; sebagian media atau alat peraga yang tersedia sudah kurang relevan dengan materi pembelajaran; dan alat peraga sederhana mulai diminati dan memungkinkan untuk dikembangkan.

Seperti halnya yang terjadi di SMP N 1 Haurwangi tempat penulis bekerja, proses pembelajaran masih belum maksimal. Hal ini bisa dilihat dari motivasi belajar peserta didik ketika proses belajar berlangsung di dalam kelas. Selama proses belajar berlangsung peserta didik banyak diam, fasif, seakan tidak mau berpikir, komunikasi yang terjadi hanya satu arah, sepertinya sangat membosankan. Begitu juga dalam hal penggunaan media pembelajaran ketika proses kegiatan belajar mengajar masih belum maksimal. 
Menyingkapi berbagai permasalahan tersebut, guru yang memiliki fungsi inovatif dituntut kreatif untuk mampu menciptakan pembaharuan, yang seyogyanya mampu meningkatkan proses belajar mengajar. Tentunya tuntutan tersebut harus direalisasikan melalui karya nyata sehari-hari, mulai dari menyusun program, menentukan bahan ajar yang tepat, memilih metode dan media pembelajaran yang relevan, serta mampu menggunakannya, dan diakhir harus diadakan suatu evaluasi. Kegiatan itu semua bertujuan agar terciptanya suatu proses belajar mengajar yang kondusif, peserta didik lebih aktif, interaktif, kreatif, belajar lebih menyenangkan, tidak membosankan, sehingga mampu meningkatkan motivasi belajar peserta didik. Ketika peserta didik memiliki motivasi, dengan sendirinya akan muncul dorongan yang kuat dari dalam dirinya. untuk mampu melatih keterampilan dan mengembangkan bakat serta mampu mengembangkan pola berpikirnya. Sehingga peserta didik akan terbiasa mampu berpikir dengan kritis.

Media atau alat peraga merupakan salah satu komponen pembelajaran yang mampu mempengaruhi keberhasilan proses belajar mengajar tidak bisa terpisahkan dari pesatnya kemajuan teknologi, diantaranya sistem komputerisasi yang setiap saat terus mengalami perkembangan. Seperti halnya "media peta tematik" dan "media CD interaktif" keduanya merupakan produk sistem komputeriasasi, yang keduanya memiliki kelebihan. "Media peta tematik" merupakan produk sistem komputerisasi dengan menggunakan program SIG (Sistem Informasi Geogrfi). memiliki beberapa manfaat diantaranya: 1) SIG dapat digunakan sebagai alat bantu utama yang interaktif dan menarik dalam rangka peningkatan wawasan dan pengetahuan. Namun, yang paling penting adalah peningkatan pembelajaran dan pendidikan bagi usia sekolah, khususnya tentang konsep lokasi, ruang, dan unsur geografis di permukaan bumi. 2) SIG menggunakan data spasial dan data atribut secara terintegrasi sehingga sistemnya memiliki kemampuan analisis spasial dan non-spasial. 3) SIG dapat memisahkan secara tegas antara bentuk tampilan dan data-datanya. Oleh karena itu, SIG memiliki kemampuan untuk mengubah tampilan dalam berbagai bentuk. 4) SIG secara mudah dapat menghasilkan berbagai peta tematik. Peta-peta tematik tersebut merupakan turunan dari petapeta lain yang data-datanya telah dimanipulasi. 5) SIG sangat membantu pekerjaan-pekerjaan yang erat hubungannya dengan bidang-bidang spasial.

Sedangkan "media CD interkatif" memiliki beberapa kelebihan diantaranya: 1) Penggunanya bisa berinteraksi dengan program computer; 2) Menambah pengetahuan. Pengetahuan yang dimaksud adalah materi pelajaran yang disajikan CD Interaktif; 3) Tampilan audio visual yang menarik. Berdasarkan latar belakang tersebut penelitian yang akan dilaksanakan mencoba membandingkan penggunaan kedua media 
tersebut dalam proses pembelajaran. Penelitian yang akan dilaksanakan diberi judul "Studi Komfaratif Penggunaan Media Peta Tematik dengan CD Interaktif Terhadapn Keterampilan Berpikir Kritis Bahan Ajar Pola Kegiatan Ekonomi Penduduk, Penggunaan Lahan dan Pola Pemukiman di SMP Negeri 1 Haurwangi Kabupaten Cianjur " Penelitian ini mengambil bahan ajar pola kegiatan ekonomi masyarakat, penggunaan lahan dan pola pemukiman di kelas VII smester 2, karena dalam pokok bahasan tersebut lebih memungkinkan pembahasannya dengan menggunakan "media peta tematik" atau menggunakan "media CD interaktif". Sehingga diharapkan pembelajaran ini akan mampu memberikan suasana baru yang mampu menciptakan proses belajar mengajar yang benar-benar bisa meningkatkan keterampilan berpikir kritis peserta didik.

\section{PROSEDUR PENELITIAN}

Penelitian ini menggunakan Desain kelompok control non-ekivalen, Ruseffendi (2010: 52) pada desain kelompok control non-ekivalen subjek tidak dikelompokan secara acak. Pengelompokan baru di lapangan sering tidak dimungkinkan. Karena itu percobaan macam ini akan lebih baik bila kelompok-kelompok yang dibandingkan serupa. Peneliti supaya berusaha agar kelompok-kelompok tersebut serupa mungkin. Jadi pada desain eksperimen ini ada pretes, perlakuan yang berbeda dan ada postes. Diagram desain eksperimennya tampak seperti di bawah ini.

$$
\begin{array}{lllllll}
0_{1} & \mathrm{X} & 0_{2} \\
& & & & 0_{1} & \mathrm{X} 1 & 0_{2} \\
0_{3} & \mathrm{X} & 0_{4} & & 0_{3} & \mathrm{X} 2 & 0_{4}
\end{array}
$$

Sumber : diadaftasi dari Ruseffendi $(1998 ; 45)$

\section{Keterangan:}

$$
\begin{aligned}
& 0_{1}=\text { Pre tes } \\
& 0_{2}=\text { Pos Tes } \\
& \mathrm{X}_{1}=\text { Treatment proses pembelajaran dengan "media peta tematik" } \\
& \mathrm{X}_{2}=\text { Treament proses pembelajaran dengan "media CD interaktif" }
\end{aligned}
$$


$0_{1}=$ derajat kemampuan sebelum perlakuan

$\mathrm{O}_{3}=$ derajat kemampuan sebelum perlakuan

$\mathrm{O}_{2}=$ derajat kemampuan setelah perlakuan proses pembelajaran dengan "media peta tematik"

$0_{4}=$ derajat kemampuan setelah perlakuan proses pembelajaran dengan "media CD interaktif"

\section{Variabel Penelitian}

Desain penelitian ini memiliki dua variabel, yaitu Variabel Treatment dan Variabel Hasil. Variabel Treatment yaitu. Variabel eksperimen adalah model pembelajaran dengan menggunakan "media peta tematik" dan "media CD interaktif”. Variabel penelitian menurut Sugiyono (2009: 61) adalah suatu atribut atau sifat atau nilai dari orang, obyak atau kegiatan yang mempunyai variasi tertentu yang ditetapkan oleh peneliti untuk dipelajari dan kemudian ditarik kesimpulan. Dalam penelitian ini terdapat dua variabel sebagai berikut.

1. Variabel bebas adalah adalah variabel yang mempengaruhi timbulnya variabel terikat (Sugiyono,2009: 61). Dalam penelitian ini variable bebasnya yaitu pembelajaran yang menggunakan "media peta tematik" dan "media CD interaktif"

2. Variabel terikat adalah variabel yang dipengaruhi atau yang menjadi akibat (Sugiyono, 2009: 61). Dalam penelitian ini variabel terikatnya adalah keterampilan berpikir kritis. Rancangan penelitian ditunjukkan oleh skema pada tabel dibawah ini:

Tabel 3.2 Rancangan Penelitian

\begin{tabular}{|l|c|c|}
\hline \multicolumn{1}{|c|}{ Media pembelajaran } & $\begin{array}{c}\text { Media peta tematik } \\
\text { (A1) }\end{array}$ & $\begin{array}{c}\text { Media CD interaktif } \\
\text { (A2) }\end{array}$ \\
\hline $\begin{array}{l}\text { Sebelum perlakuan } \\
\text { B1 }\end{array}$ & A1 B1 & A2 B1 \\
\hline $\begin{array}{l}\text { Setelah perlakuan } \\
\text { B2 }\end{array}$ & A1 B2 & A2 B2 \\
\hline
\end{tabular}

Keterangan:

A1B1: Keterampilan berpikir kritis peserta didik pada pembelajaran yang menggunakan "media peta tematik" sebelum perlakuan.

A1B2: Keterampilan berpikir kritis peserta didik pada pembelajaran yang menggunakan "media peta tematik" setelah perlakuan. 
A2B1: Keterampilan berpikir kritis peserta didik pada pembelajaran yang menggunakan “media CD interaktif” sebelum perlakuan.

A2B2: Keterampilan berpikir kritis peserta didik pada pembelajaran yang menggunakan “media CD interaktif”, setelah perlakuan.

\section{Diagram Alur Penelitian}

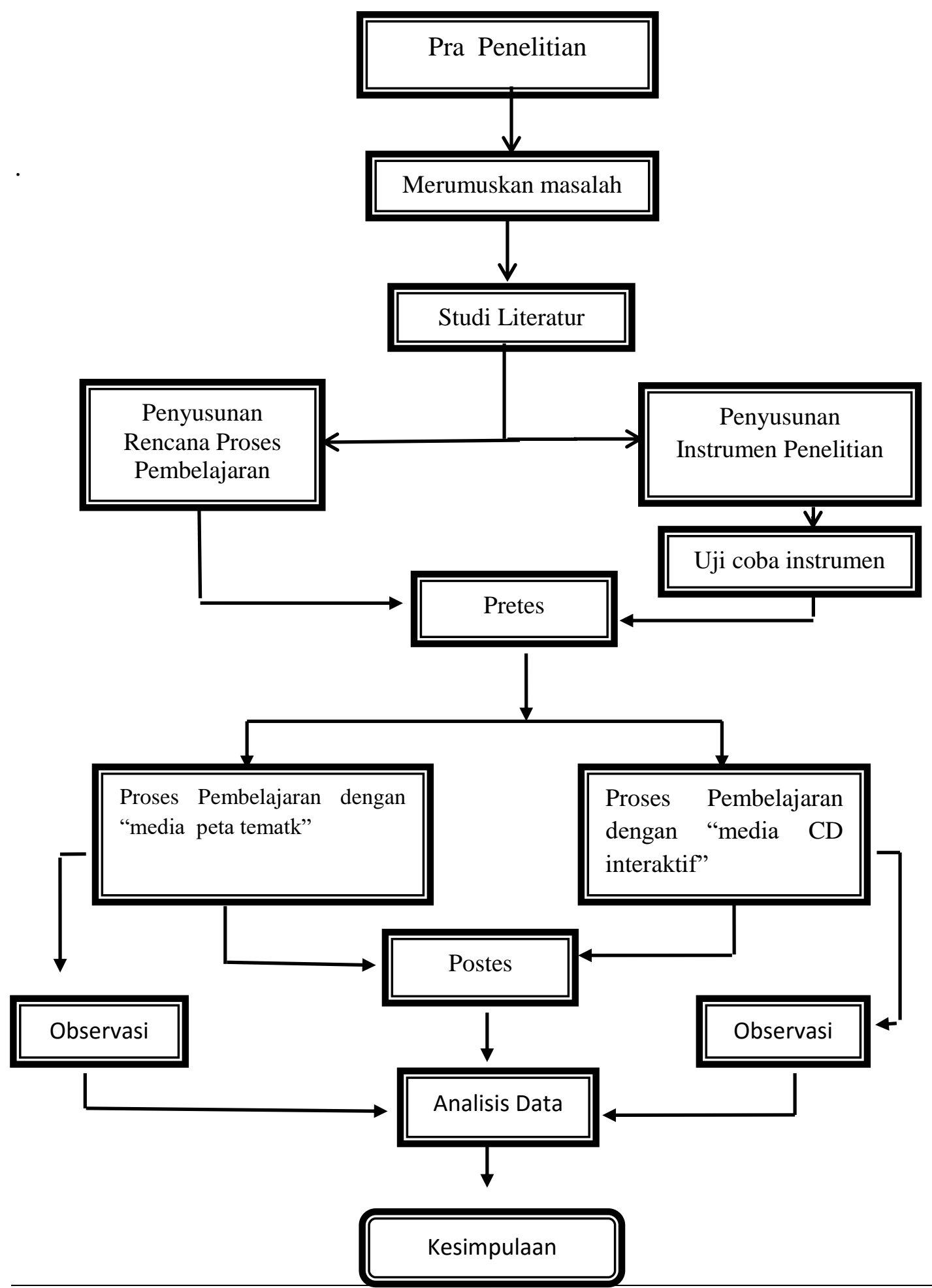




\section{PEMBAHASAN HASIL PENELITIAN}

Prosentase perubahan keterampilan berpikir kritis "kelas eksperimen-1" sebelum dan sesudah perlakuan. Prosentase perubahan keterampilan berpikir kritis sebelum dan sesudah proses pembelajaran di "kelas eksperimen-1", dengan proses pembelajaran menggunakan "media peta tematik" pada bahan ajar pola kegiatan ekonomi penduduk, penggunaan lahan dan pola pemukiman sebesar 28,62, dengan nilai gain sebesar 0,451 Besar perubahan hasil sebelum dan sesudah proses pembelajaran berada dibawah 30\%. termasuk katagori sangat rendah, sedangkan berdasarkan $\mathrm{N}$-gain perubahan keterampilan berpikir kritis sebelum dan sesudah perlakuan termasuk kategori sedang karena ada diantara $0,3<0,7$.

Pemahaman peserta didik di "kelas eksperimen-1" hasil postes ditunjukkan oleh nilai uji-T. Dari tabel di atas didapat T hitung sebesar 4,377, sedangkan Nilai T-tabel sebesar 2,023 dengan demikian $\mathrm{T}$ hitung $>\mathrm{T}$ tabel artinya dapat disimpulkan bahwa terdapat pengaruh penggunaan "media peta tematik" terhadap keterampilan berpikir kritis pada bahan ajar pola kegiatan ekonomi Penduduk, penggunan lahan dan pola pemukiman.

\section{Prosentase Perbedaan Nilai Postes Keterampilan Berpikir Kritis "Kelas Eksperimen-1" dan "Kelas Eksperimen-2"}

Prosentase perubahan keterampilan berpikir kritis sebelum dan sesudah proses pembelajaran di "kelas eksperimen-2", dengan proses pembelajaran menggunakan "media peta tematik" pada bahan ajar pola kegiatan ekonomi penduduk, penggunaan lahan dan pola pemukiman sebesar 22,67\%, dengan nilai gain sebesar 0,390 Besar perubahan hasil sebelum dan sesudah proses pembelajaran berada dibawah 30\%. termasuk katagori sangat rendah, sedangkan berdasarkan $\mathrm{N}$-gain perubahan keterampilan berpikir kritis sebelum dan sesudah perlakuan termasuk kategori sedang karena ada diantara 0,3 <0,7. Berdasarkan tabel 4.10, menunjukkan bahwa pemahaman peserta didik di "kelas eksperimen-2" hasil postes ditunjukkan oleh nilai uji-T. Dari tabel di atas didapat T hitung sebesar 6.062, sedangkan Nilai T tabel sebesar 2,023 dengan demikian T hitung > T tabel artinya Ho ditolak dan Hi diterima dapat disimpulkan bahwa terdapat pengaruh penggunaan "media CD interaktif" terhadap keterampilan berpikir kritis.

\section{Prosentase Perbedaan Nilai Postes Keterampilan Berpikir Kritis "Kelas Eksperimen-1" dan "Kelas Eksperimen-2"}


Prosentase perbedaan keterampilan berpikir kritis antara "kelas eksperimen-1" yang pembelajarannya menggunakan "media peta tematik," dan "kelas eksperimen-2" yang pembelajarannya menggunakan "media CD interaktif" pada bahan ajar pola ekonomi penduduk, penggunaan lahan dan pola pemukiman, perbedaan prosentasenya sebesar $05,96 \%$ ternyata kurang dari $30 \%$. Mengacu pada perbandingan angka prosentase berada diantara 0 $39 \%$ dapat diartikan perbedaan keberhasil proses pembelajaran kedua kelas tersebut "kelas eksperimen-1" yang pembelajarannya menggunakan "media peta tematik" dengan "kelas eksperimen-2" yang pembelajarannya menggunakan "media CD interaktif" dikategorikan sangat kurang.

Hasil dari uji-T menunjukkan bahwa perbedaan keterampilan berpikir kritis peserta didik di "kelas eksperimen-1" hasil postes ditunjukkan oleh uji-T. Hasilnya T hitung sebesar 7,451, sedangkan Nilai $\mathrm{T}$ tabel sebesar 2,023 dengan demikian $\mathrm{T}$ hitung $>\mathrm{T}$ tabel artinya Ho ditolak dan Hi diterima dapat disimpulkan bahwa adanya perbedaan hasil keterampilan berpikir kritis antara proses pembelajaran yang menggunakan "media peta tematik" dan "media CD interaktif"

\section{Tanggapan Guru Terhadap Proses Pembelajaran Dengan "Media Peta Tematik"}

Memperhatikan penyebaran jawaban guru pada tabel 4.16 di atas prosentase hasil tanggapan guru terhadap pembelajaran yang menggunakan "media peta tematik" sebesar $84,00 \%$. Artinya dapat disimpulkan penggunaan "media peta tematik" pada bahan ajar pola ekonomi penduduk, penggunaan lahan dan pola pemukiman direspon positif. Dapat disimpulkan bahwa tanggapan guru terhadap proses pembelajaran di "kelas eksperimen-1" yang pembelajarannya menggunakan "media peta tematik" termasuk sangat tinggi karena prosentase rata-ratanya diantara $80-100 \%$.

Alasan tanggapan guru terhadap pembelajaran yang menggunakan "media peta tematik" mencapai prosentase sangat tinggi karena penggunaan media tersebut relatif jarang dilakukan dalam prosres pembelajaran sehari-hari. Menurutnya penggunaan peta tematik yang menyajikan data di lapangan peserta didik lebih termotivasi selama proses pembelajaran.

\section{Tanggapan Guru Terhadap Proses Pembelajaran Dengan "Media CD Interaktifk"}

Memperhatikan penyebaran jawaban guru pada tabel 4.17 prosentase hasil tanggapan guru terhadap pembelajaran "media CD interaktif” sebesar 78,00\%. Artinya dapat disimpulkan bahwa penggunaan "media CD interaktif" pada bahan ajar pola kegiatan ekonomi penduduk, 
penggunaan lahan dan pola pemukiman termasuk tinggi karena prosentase rata-ratanya diantara $66-79 \%$. Alasan tanggapan guru terhadap pembelajaran yang menggunakan "media CD interaktif" mencapai prosentase kategori tinggi karena merupakan hal yang baru dilaksanakan dalam proses pembelajaran di kelas VII. Sehingga peserta didik lebih merasa tertarik dan termotivasi selama proses pembelajaran.

\section{Tanggapan Peserta Didik Terhadap Proses Pembelajaran Dengan "Media Peta Tematik". dan "Media CD Interaktif"}

Berdasarkan tabel 4.18, rata-rata prosentase tanggapan peserta didik terhadap "kelas eksperimen-1" yang pembelajarannya menggunakan "media peta tematik" sebesar 87,74\%. Dapat disimpulkan bahwa tanggapan peserta didik dalam proses pembelajaran di "kelas eksperimen-1" termasuk sangat tinggi karena prosentase rata-ratanya diantara $80-100 \%$. Sedangkan tanggapan peserta didik terhadap "kelas eksperimen-2" yang pembelajarannya menggunakan "media CD interaktif" sebesar 84,66\%. Dapat disimpulkan bahwa tanggapan peserta didik dalam proses pembelajaran di "kelas eksperimen-2" juga termasuk sangat tinggi. Patut diduga tanggapan peserta didik dari kedua proses pelaksanaan pembelajaran baik di kelas eksperimen-1 dan kelas eksperimen-2 termasuk kategori sangat tinggi disebabkan proses pembelajaran yang dilaksanakan dengan menggunakan "media peta tematik" dan "media CD interaktif" merupakan hal yang baru. Sehingga peserta didik termotivasi untuk mengikuti proses pembelajaran.

\section{KESIMPULAN}

Berdasarkan permasalahan dan tujuan dari penelitian dengan didasari hasil analisis dan pembahasan secara garis besar dapat disimpulkan sebagai berikut:

1. Pembelajaran dengan menggunakan "media peta tematik" dan "media CD interaktif " khususnya pada bahan ajar pola ekonomi penduduk, penggunaan lahan dan pola pemukiman, menggambarkan hasil yang kurang memuaskan, hal ini dapat dilihat dari angka prosesntase perubahan hasil keterampilan berpikir kritis pada masing-masing kelas eksperimen. Kelas eksperimen-1 yang menggunakan "media peta tematik" perubahan hasil keterampilan berpikir kritis sebelum dan sesudah perlakuan sebesar 28,62 \% (termasuk kategori sangat rendah). Sedangkan kelas eksperimen-2 yang pembelajarannya menggunakan "media CD interaktif" perubahan hasil keterampilan berpikir kritis sebelum dan sesudah perlakuan sebesar 22,67 \% (sangat rendah). Melihat dari gambaran hasil 
penelitian yang termasuk kategori sangat rendan dihubungkan dengan gambaran kondisi sekolah yang dijadikan tempat penelitian, khususnya mengenai "input peserta didik" yang ketika penerimaan peserta didik barunya tanpa melalui tes penyaringan, maka ini dapat dijadikan salah satu alasan penyebab dari sangat rendahnya hasil prosentase perubahan keterampilan berpikir kritis sebelum dan sesudah perlakuan pada penelitian ini.

2. Dari hasil penelitian yang didapat perbandingan proses pembelajaran dengan menggunakan "media peta tematik" dan "media CD interaktif" pada bahan ajar pola ekonomi penduduk, penggunaan lahan dan pola pemukiman menunjukkan bahwa proses pembelajaran yang menggunakan "media peta tematik" hasilnya lebih baik dibanding pembelajaran yang menggunakan "media CD interaktif". Bisa di duga alasannya karena media peta tematik yang digunakan dibuat dengan sederhana dan disesuaikan dengan tema bahan ajar yang disampaikan, kemudia berdasarkan hasil angket bahwa penggunaan media peta tematik buat peserta didik yang baru sesmeter 1 merupakan hal yang baru sehingga mereka cukup antusias dan termotivasi dalam proses pembelajaran.

3. Tanggapan guru terhadap proses pembelajaran dengan menggunakan "media peta tematik" sangat positf. Guru menanggapinya bahwa pembelajaran yang menggunakan "media peta tematik" di tingkat SMP merupakan hal yang baru dilaksanakan, sehingga memberikan suasana baru terhadap proses pembelajaran, serta pembelajaran ini bisa dijadikan salah satu alternatif untuk meningkatkan keterampilan berpikir kritis khususnya pada bahan ajar pola ekonomi penduduk, penggunaan lahan dan pola pemukiman.

4. Tanggapan peserta didik terhadap pembelajaran dengan menggunakan "media peta tematik" dan proses pembelajaran yang menggunakan "media CD interaktif" pada bahan ajar pola ekonomi penduduk, penggunaan lahan dan pola pemukiman kedua positif. Peserta didik mengemukan bahwa proses pembelajaran yang dilasanakan merupakan hal yang sangat berbeda dari pembelajaran yang keseharian dilaksanakan. mereka menyatakan sangat senang dengan proses pembelajaran yang dilaksanakan.

\section{DAFTAR PUSTAKA}

Arikunto,S.(2006). Prosedur Penelitian Suatu Pendekatan Praktik. Jakarta : Rineka Cipta. . (2005). Manajemen Penelitian. Jakarta: Rineka Cipta. . (1995).Dasar-dasar Evaluasi Pendidikan. Jakarta: PT. Bumi Aksara.

Azwar, S. (1987) Tes Prestasi. Yogjakarta: Liberty. 
Jurnal Gea Volume 14 Nomor 2, Oktober 2014

BNSP. (2007). Standar Proses untuk Satuan Pendidikan Dasar Menengah. Jakarta: Badan

Standar Nasional Pendidikan.

Daryanto. (2008). Dasar Evaluasi Pendidikan. Jakarta: Rineka Cipta.

Emzir, (2008). Metodologi Penelitian Pendidikan, Jakarta: Raja Grafindo.

Fisher, A. (2008). Berpikir Kritis Sebuah Pengantar. Erlangga

Hadi, S. (2004). Metodologi Research. Jilid 4. Yogyakarta: Andi.

Hossoubah, Z. Develoving Creative and Critical Thinking Skills (terjemahan) . 2004.

Bandung: Yayasan Nuansa Cendia

Kusnendi. (2008). Model-Model Persamaan Struktural, Satu dan Multi Group Sampel dengan Lisrel, Bandung: Alfabeta.

Kraak dan Ormeling (2013). Kartografi Visualisasi Data Geospasial (Terjemah). Yogyakarta : Gajah Mada Ubiversity Press.

Nasution,S. (1985). Berbagai Pendekatan dalam Proses Belajar dan Mengajar. Jakarta: Bina Aksara.

Nugroho, Y.A., (2011). It’s Easy, Olah Data dengan SPSS. Yogyakarta : Skripta.

Nurdin, Moh. Dkk. (2008). Ilmu Pengetahuan Sosial untuk SMP/MTS Kelas VII. Jakarta : CV. Arya Duta.

Pusat Pembinaan dan Pengembangan Bahasa, (1997). Kamus Besar Bahasa Indonesia, Jakarta : Balai Pustaka.

Prahasta, E. (2009). Sistem Informasi Geografis Konsep-Konsep Dasar (Perspektif Geodesi \& Geomatka). Bandung Informatik.

Ruseffendi, H.E.T. (1998). Statistika Dasar Untuk Penelitian Pendidikan. Bandung : CV. Andira

Sadiman, A.S. (2004)., Media Pendidikan : Pengertian, Pengembangan dan Pemanfaatannya. Jakarta: PT Raja Grafindo Persada.

Samsudin, A.(2008) Penggunaan Model Pembelajaran Multi Media Interaktif (MMI) Optika Geometri untuk Meningkatkan Penguasaan Konsep dan Memperbaiki Sikap Belajar Siswa. Bandung: Tesis SPs UPI: Tidak diterbitkan

Sudjana, N. (2005). Penilaian Hasil Proses Belajar. Bandung: PT. Remaja Rosdakarya Offset.

Suharto.K. (2003). Teknologi Pembelajaran (Pendekatan Sistem, Konsepsi dan Model, SAP, Evaluasi, Sumber Belajar dan Media). Surabaya: Surabaya Intelectual Club.

Supriya, dkk (2003). Strategi Pembelajaran IPS, Jakarta: Pusat Penerbitan Universitas Terbuka.

Sugiyono. (2006). Statistika Untuk Penelitian. Bandung: CV. Alfabeta 